\title{
PENYELESAIAN MASALAH MATEMATIKA \\ PADA TIPE KEPRIBADIAN PHLEGMATIS
}

\author{
Rina Agustina \\ FKIP Universitas Muhammadiyah Metro \\ E-mail : aasyiqun1212@gmail.com
}

\begin{abstract}
The research was a descriptive qualitative. The prosedure of selecting the subjects used purposive sampling. The data of the research was collected by using think aloud method. The validity of the data used was triangulation. The results of the research showed that problem solving of personality type phlegmatic: (a) understanding the information by looking at the questions, then making a picture, had no difficulty in turning information into mathematical form and looking back at the questions to find the things in questions, (b) solving the problems by planning $a$ solution that is started from the specified requirements in the matter, experiencing difficulty to change the equation initial information to be used in the calculation, and was not able to find the other formula which was different from the derivative function; (c) convincing the answer by looking back at the existing calculation, adjusting the obtained solution that was based on actual event and re-adjusting it to the problem in question.
\end{abstract}

Keywords: problem solving, personality type phlegmatic.

\section{PENDAHULUAN}

Pemecahan masalah dalam matematika merupakan salah satu kompetensi dasar yang harus dimiliki oleh siswa. Siswa harus bisa menerapkan ilmu yang didapat ketika dihadapkan dengan masalah dalam kehidupan sehari-hari. Pada saat pembelajaran, siswa sering diberikan soal dalam bentuk abstrak namun kebanyakan tidak terbiasa untuk mengubah masalah dalam bentuk matematika. Siswa hanya mengetahui matematika sebatas kumpulan rumus saja, padahal matematika sangat berguna untuk menyelesaikan masalah dalam kehidupan sehari-hari. Oleh karena itu, siswa memiliki kemampuan yang kurang dalam menganalisis dan menyelesaikan masalah matematika.

16 | Aksioma Jurnal Pendidikan Matematika FKIP Univ. Muhammadiyah Metro 
Menurut Dewiyani (2008), di dalam dunia pendidikan matematika, sebagian besar ahli pendidikan matematika menyatakan bahwa masalah merupakan pertanyaan atau soal matematika yang harus dijawab atau direspon. Suatu pertanyaan akan menjadi masalah hanya jika pertanyaan itu menunjukkan adanya suatu tantangan (challenge) yang tidak dapat dipecahkan oleh suatu prosedur rutin yang telah diketahui si pelaku.

Menurut Dewey (dalam Bilgin dan Karakirik, 2005), "A problem is defined broadly as what one does when one does not know what to do". Makna kalimat tersebut adalah sebuah masalah didefinisikan secara luas sebagai apa yang dilakukan seseorang ketika seseorang tidak tahu apa yang harus dilakukan.

Dari uraian di atas, yang dimaksud masalah dalam penelitian ini adalah kondisi dimana siswa merasa mendapat tantangan dan hambatan ketika diberikan soal matematika. Siswa merasa terdapat kesulitan dalam menyelesaikan soal yang diberikan dan mencoba mencari penyelesaian dari masalah tersebut.

Salah satu materi dalam matematika adalah aplikasi turunan fungsi. Pada kelas XI SMA IPA kompetensi dasar materi aplikasi turunan fungsi adalah menggunakan turunan untuk menentukan karakteristik suatu fungsi dan memecahkan masalah. Masalah dalam aplikasi turunan fungsi berupa soal pemecahan masalah dalam kehidupan sehari-hari yang akan diubah ke dalam bentuk matematika.

Menurut Gagne's (dalam Kirkley, 2003: 7), problem solving as the "synthesis of other rules and concepts into higher order rules which can be applied to a constrained situation." Problem solving also includes attitudinal as well as cognitive components. To solve problems, learners have to want to do so, and they have to believe they can. Motivation and attitudinal aspects such as effort, confidence, anxiety, persistence and knowledge about self are important to the problem solving process.

Makna kalimat di atas adalah Gagne mendefinisikan pemecahan masalah sebagai sintesis aturan lain dan konsep ke dalam aturan yang lebih tinggi yang dapat diterapkan pada situasi tertentu. Pemecahan masalah juga termasuk komponen sikap serta kognitif. Untuk mengatasi masalah, siswa harus memiliki keinginan untuk melakukannya, dan mereka harus percaya mereka bisa. Motivasi dan aspek-aspek seperti upaya, keyakinan, ketekunan kecemasan, dan pemahaman diri adalah hal yang penting untuk proses pemecahan masalah.

Menurut Ormrod (2008: 393), pemecahan masalah memerlukan pengetahuan dan keterampilan yang sudah ada untuk menjawab pertanyaan yang belum terjawab atau situasi yang sulit. Kita biasanya mengasosiasikan 
pemecahan masalah dengan matematika dan sains, namun sebenarnya pemecahan masalah itu dapat terjadi secara nyata pada semua konten.

Pemecahan

masalah matematika melibatkan aktifitas kognitif siswa. Menurut Mustamin Anggo (2011: 25), proses berpikir dalam pemecahan masalah merupakan hal penting yang perlu mendapat perhatian para pendidik terutama untuk membantu siswa agar dapat mengembangkan kemampuannya memecahkan masalah. Sesuai dengan pendapat Lester (dalam Mustamin Anggo, 2011: 25) bahwa tujuan utama mengajarkan pemecahan masalah dalam matematika adalah tidak hanya untuk melengkapi siswa dengan sekumpulan keterampilan atau proses, tetapi lebih kepada memungkinkan siswa berpikir tentang apa yang dipikirkannya.

Menurut Kim (2002), one assumption is that talking is a positive act, and there are at least two reasons for this. First, talking is a positive act because it is an expression of the individual. Talking is a basic means through which individuals express their ideas, points of view. Therefore, the effort to encourage verbal expression of thoughts is a good and justifiable act. Second, talking is a positive act because it is closely connected with thinking. Language and its verbal expression in talking can create, change, and signify thinking.
Makna kalimat di atas adalah salah satu asumsi adalah bahwa berbicara adalah tindakan positif karena ada dua alasan. Pertama, berbicara adalah tindakan positif karena merupakan ekspresi dari individu. Berbicara merupakan sarana dasar individu mengekspresikan ide dan sudut pandang mereka. Oleh karena itu, upaya untuk mendorong ekspresi verbal dari pikiran adalah tindakan yang baik dan dibenarkan. Kedua, berbicara adalah tindakan positif karena sangat berhubungan dengan pemikiran. Bahasa dan ekspresi verbal dalam berbicara dapat membuat, mengubah, dan menandakan berpikir.

Proses berpikir masing-masing dapat dipengaruhi oleh tipe kepribadian yang dimiliki. Setiap siswa memiliki tipe kepribadian yang berbeda, sehingga proses berpikir siswa dalam menyelesaikan masalah matematika juga berbeda.

Penelitian ini membahas tentang tipe kepribadian phlegmatic pada siswa. Dalam Sumadi Suryabrata (2008: 56), Kart menguraikan phlegma berarti ketidaklembaman, jadi berarti tidak malas. Phlegma sebagai kelemahan ialah kecenderungan ke arah menyebabkan adanya kecenderungan ke arah kejemuan dan mengantuk. Phlegma sebagai kekuatan sebaliknya, merupakan sifat yang tidak mudah bergerak tetapi kalau sudah bergerak lalu tahan lama. Sifat-sifat khas golongan temperamen ini ialah: 
ketidakpekaan; alasan yang kuat tidak cukup untuk merangsangnya untuk bertindak; ketidakpekaan ini
a. Lambat menjadi panas, tetapi panasnya itu tahan lama,
b. Tidak mudah marah,
c. Darah yang dingin itu tak pernah dirisaukannya,
d. Cocok untuk tugas-tugas ilmiah.

\section{METODE PENELITIAN}

Jenis penelitian ini adalah penelitian kualitatif deskriptif. Waktu penelitian merupakan lamanya penelitian berlangsung, mulai dari persiapan sampai penyusunan laporan penelitian. Adapun alasan pemilihan lokasi penelitian, yaitu:
a. Sekolah memiliki data dan informasi yang dibutuhkan untuk kepentingan penelitian.
b. Pada sekolah tersebut belum pernah dilakukan penelitian yang sejenis.

Data dalam penelitian ini berupa informasi yang menggambarkan cara penyelesaian masalah matematika pada tipe kepribadian phlegmatis. method, yaitu siswa diminta untuk mengungkapkan ekpresi verbal tentang ide yang dipikirkan ketika menyelesaikan soal aplikasi turunan fungsi.

Untuk mendapatkan data yang valid dilakukan langkah-langkah sebagai berikut:
1. Melakukan pengambilan data proses berpikir siswa dengan think aloud method yaitu siswa mengungkapkan ide pikiran secara verbal ketika mengerjakan soal pemecahan masalah.

2. Menganalisis hasil think aloud pada pengambilan data pertama.

3. Melakukan pengambilan data kedua untuk melihat validitas hasil pengambilan data pertama.

4. Membandingkan hasil pengambilan data pertama dengan pengambilan data kedua.

5. Data dikatakan valid apabila terdapat konsistensi pada hasil pengambilan data pertama dan pengambilan data kedua, serta kedua data tersebut menggambarkan proses berpikir siswa.

Analisis data kualitatif dalam penelitian ini dilakukan secara interaktif dan berlangsung secara terus menerus sampai tuntas dan didapatkan data proses berpikir siswa. Aktivitas dalam analisis data, yaitu reduksi data, penyajian data, penarikan kesimpulan.

\section{HASIL PENELITIAN DAN PEMBAHASAN}

Setelah dilakukan pengambilan data, didapatkan hasil penelitian sebagai berikut: 


\section{1) Memahami Informasi}

Salah satu indikator untuk memahami informasi adalah bagaimana respon siswa ketika diberi masalah. Ketika menerima soal, siswa phlegmatic merasa siap dan tersenyum. Siswa phlegmatic melihat soal dan memaknai informasi yang ada kemudian membuat gambar. Siswa phlegmatic tidak mengalami kesulitan untuk mengetahui hal yang ditanyakan pada soal.

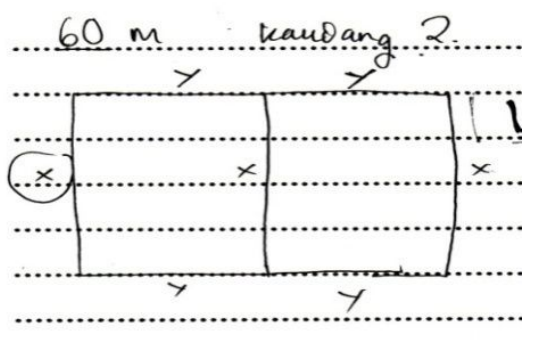

Setelah memahami informasi pada soal, siswa phlegmatis mencoba mengubah informasi tersebut ke dalam bentuk matematika. Untuk mengubah informasi ke dalam bentuk matematika, siswa phlegmatis menggunakan notasi $x$ untuk panjang dan $y$ untuk lebar dengan alasan agar lebih memudahkan dalam perhitungan

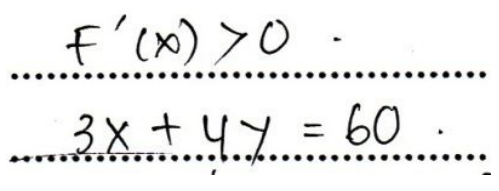

Berdasarkan analisis diatas, diketahui bahwa siswa phlegmatis dapat memahami informasi dengan cara sebagai berikut.

1. Melihat soal kemudian membuat gambar.

2. Memahami yang diketahui dengan mengubah informasi ke bentuk matematika.

3. Melihat soal kembali untuk mengetahui hal yang ditanyakan.

\section{2) Menyelesaikan Masalah}

Rencana penyelesaian yang dibuat oleh siswa merupakan salah satu indikator dalam kategori menyelesaikan masalah. Siswa phlegmatis membuat rencana penyelesaian dengan mencari luas maksimum menggunakan cara turunan fungsi.
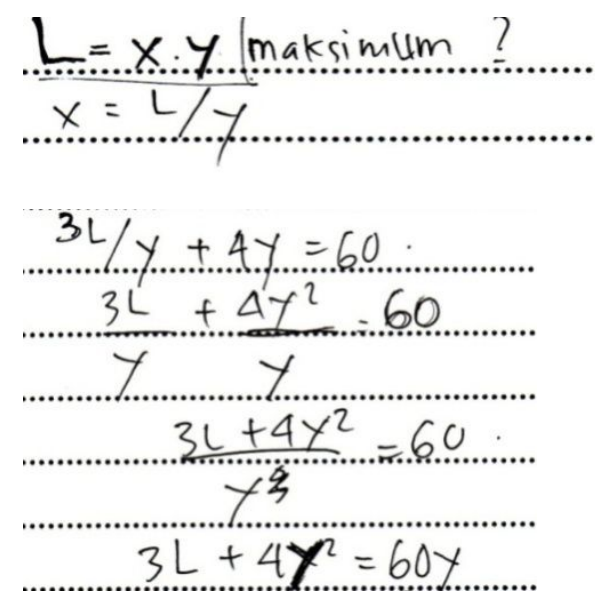

Setelah mengubah persamaan $3 x+4 y=60$ menjadi $\mathrm{x}=$, siswa phlegmatis mulai mencari ukuran lebar pada soal dengan cara turunan fungsi. 
Setelah didapatkan ukuran lebar, siswa phlegmatis mencari ukuran panjang dengan menggunakan rumus pada informasi awal.

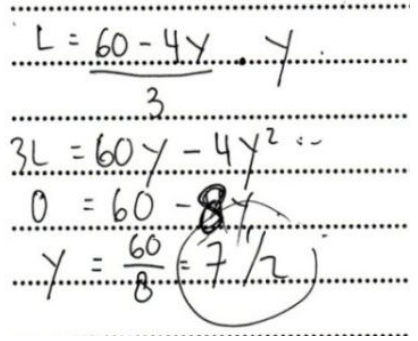

Berdasarkan analisis diatas, diketahui bahwa siswa phlegmatis dapat menyelesaikan masalah dengan cara sebagai berikut.

1. Membuat rencana penyelesaian dengan baik.

2. Menghubungkan persamaan awal dengan rencana penyelesaian meskipun mengalami kesulitan.

3. Menyelesaikan masalah sesuai dengan rencana penyelesaian.

4. Menyelesaikan hanya dengan satu cara.

\section{3) Meyakinkan Jawaban}

Untuk meyakinkan jawaban yang didapat, siswa phlegmatic melihat kembali pada perhitungan yang telah dilakukan.Siswa phlegmatic yakin dengan jawaban yang didapat dikarenakan telah melalui perhitungan yang tepat. Siswa phlegmatic yakin dengan perhitungan yang ada dikarenakan perhitungan dilakukan dengan hati-hati. Dari penyelesaian yang diperoleh, siswa phlegmatic menyesuaikan jawaban dengan kejadian yang sesungguhnya.

Berdasarkan analisis di atas, diketahui bahwa siswa $\mathrm{L}$ dapat menyelesaikan masalah dengan cara sebagai berikut.

1. Melihat kembali perhitungan pada lembar jawaban.

2. Menyesuaikan jawaban dengan kejadian yang sebenarnya.

Hasil analisis pada siswa L sesuai dengan teori Tipologi Hippocrates-Galenus yang menyatakan bahwa tipe kerpibadian phlegmatis dalam menyelesaikan sebuah pekerjaan memiliki sifat, yaitu: cakap dan mantap, damai dan mudah sepakat, punya kemampuan administratif, menjadi penengah masalah, menghindari konflik, dan menemukan cara yang mudah. Selain itu, siswa dengan tipe kepribadian phlegmatis: kepribadian rendah hati, mudah bergaul dan santai, diam, tenang, sabar, baik keseimbangannya, hidup konsisten, tenang tetapi cerdas, simpatik dan baik hati, menyembunyikan emosi, dan bahagia menerima kehidupan.

\section{KESIMPULAN}

Berdasarkan hasil analisis data dan pembahasan, maka dapat disimpulkan bahwa penyelesaian masalah matematika pada tipe kepribadian 
phlegmatis, yaitu: memahami informasi dengan cara melihat soal kemudian membuat gambar, memahami yang diketahui dengan mengubah informasi ke bentuk matematika, dan melihat soal untuk mengetahui yang ditanyakan, menyelesaikan masalah membuat dengan perencanaan yang baik, menghubungkan persamaan awal dengan rencana penyelesaian meskipun mengalami kesulitan, menyelesaikan masalah sesuai dengan perencanaan tetapi hanya dengan satu cara, dalam meyakinkan jawaban dengan melihat jawaban kembali dan menyesuaikan dengan kejadian sebenarnya.

\section{DAFTAR PUSTAKA}

Bilgin, I dan Karakirik, E. 2005. A Computer Based Problem Solving Environment in Chemistry. The Turkish Online Journal of Educational Technology.Vol4, No. 3, pp7 11.

Dewiyani. 2008. Mengajarkan Pemecahan Masalah dengan Menggunakan Langkah Polya. Stikom Jurnal .Vol. 12, No 2, pp $87-95$.

Kim, H. S. 2002. We Talk, Therefore We Think? A Cultural Analysisof the Effect of Talking on Thinking. Journal of Personality and Social Psychology. Vol. 83, No. 4, pp 828-842.
Kirkley, J. 2003. Principles for Teaching Problem Solving.Plato Learning.

Mustamin Anggo. 2011. Pelibatan Metakognisi dalam Pemecahan Masalah Matematika. Edumatica. ISSN: 2088-2157.Vol.1, No.1, pp $25-32$.

Ormrod, J. E. 2008. Psikologi Pendidikan (Membantu Siswa Tumbuhdan Berkembang). Penerjemah: Amitya Kumara. Erlangga. Jakarta.

Sumadi Suryabrata. 2008. Psikologi Kepribadian. Raja Grafindo Persada. Jakarta. 